\title{
Raymond Williams
}

\section{Realismi ja nykyromaani ${ }^{1}$}

Kärsimme realistisen romaanin rapautumisesta ja maineenmenetyksestä. Kuitenkin realistisen romaanin elvyttäminen olisi tarkoitustemme mukaista sillä kuten tiedämme, olemme yksilöitä yhteiskunnassa, sen puitteissa. Tietenkään emme voi vain toistaa George Eliotia tai edes Lawrencea, vaikka juuret ovatkin heissä. Mutta luullakseni tarvittava suunta on siellä päin.

Kun äskettäin kirjoitin näin arvioidessani The Uses of Literacya, aavistin joutuvani pian vahvistamaan ja selventämään väitettäni. Yhtäältä väite on vastoin uusinta kriittistä ajattelua ja omiaan herättämään reaktion, jonka kohta kuulinkin: että realistinen romaani "meni muodista vossikan myötä". Toisaalta tiesin itsekin, kuinka voimakas mutta epämääräinen sana "realismi" voi olla. Onhan helppoa julistaa puoltavansa realismia, mutta vaikea sanoa, mitä siihen tarkalleen ottaen sisällyttääkään.

Perustellakseni kantani kokonaan tarvitsisin oikeastaan enemmän tilaa kuin minulla oli silloin tai on nyt. Tärkeä keskustelu on kuitenkin meneillään, ja on korkea aika esittää tämä argumentti, vaikka sitten hieman uudelleen muotoilemisen tarvetta jättäen. Niinpä yritän kertoa tässä, mitä tarkoitan realistisella romaanilla ja miksi pidän sen elvyttämistä välttämättömänä. Loput perusteluni seuratkoot myöhemmin, mutta kenties tulen esittäneeksi joitakin seikkoja, joihin tarttua keskustelussa jo nyt.

\section{[Romaani ja realistinen traditio] ${ }^{2}$}

Romaani ei ole niinkään kirjallinen muoto kuin kirjallisuuden kokonaisuus itsessään. Sen laajojen rajojen puitteissa on tilaa melkeinpä millaiselle vain nykykirjoittamiselle. Fiktion traditiolle ja siitä käytävälle kriittiselle keskustelulle tehdään suurta hallaa, jos "romaani” samastetaan vain yhdentapaiseen proosatyöhön. Juuri sellainen riittämätön määrittely sai Tolstoin sanomaan Sodasta ja rauhasta, ettei se ole romaani. Tosiasiassa muotoon kuuluvat niin Middlemarch kuin Sokeat, niin Humiseva harju kuin Huckleberry Finn, niin The Rainbow kuin Taikavuori, ja sellaisena se muistuttaa kirjallisuuden kokonaisuutta. Kun nyt sitten sanon, että uskon tiettyyn suuntaan, realistisen romaanin elvyttämiseen, en tokikaan halua sulkea romaanin avaraa muotoa yhteen erityiseen teosten tyyppiin. Sen sijaan korostan, että aikamme kirjallisuudessa on muodollinen kuilu, joka estää sitä pätevästi ilmaisemasta tietynlaista, erityisen tärkeänä pitämääni kokemusta. Tein aiemman ehdotukseni silloittaakseni tuota kuilua, ja viittaus George Eliotiin ja Lawrenceen oli pieni yritys osoittaa tarkoittamaani kokemukseen.

Yleisemmin sanottuna tarkoitan seuraavaa. On tietynlainen romaani, joka tapaa luoda ja arvottaa kokonaisen elämäntavan laatua henkilöiden laatujen kannalta katsoen. 
Tasapaino, joka tähän saavutukseen sisältyy, on asiassa kenties kaikkein tärkeintä. Se näyttää äkkiseltään hyvin yleiseltä seikalta, sellaiselta, mitä useimmat romaanit tekevät; juuri sitähän Sota ja rauha, Middlemarch ja The Rainbow tekevät. Mutta on nimenomaan tämän tradition ominaispiirre tarkastella luomuksissaan koko elämäntapaa eli yhteiskuntaa, joka on suurempi kuin yksikään sitä koostavista yksilöistä, ja yksilöllisiä ihmishahmoja, jotka kuuluessaan tuohon elämäntapaan, vaikuttuessaan siitä ja auttaessaan muotoilemaan sitä ovat tavallansa myös itsessään kiistattomia päämääriä. Kumpikaan elementti, sen kummemmin yhteiskunta kuin yksilökään, ei esiinny ensisijaisena. Yhteiskunta ei ole taka-ala, jota vasten henkilösuhteita tarkastellaan, eivätkä yksilöt ole ainoastaan elämäntavan aspektien kuvitusta. Kutsun tätä realistiseksi traditioksi, koska nähdäkseni tietty kypsä realismi havainnollistaa kokemuksellisesti juuri sitä. Tällaista elämä on, sanoisin - millaisena yritän sen kokonaisuudessaan nähdä. Yleinen elämä vaikuttaa perinpohjin jokaiseen henkilökohtaiseen elämänaspektiin, ja silti yleinen saa tärkeimmän merkityksensä mitä henkilökohtaisimmassa valossa. Meidän on herkistyttävä kaiken tajumme voimin yleisen elämän piirteille, mutta niiden ytimenä on aina yksilöllinen ihmispersoona - ei tosin mikä vain eristynyt persoona, vaan ne monet, jotka ovat yleisen elämän todellisuus. Etenkin Tolstoi ja George Eliot sanoivat usein yrittäneensä toteuttaa teoksissaan tämäntapaista näkemystä elämästä.

Nyttemmin traditio sellaisenaan on särkynyt. En edelleenkään tarkoita sitoa sitä mihinkään erityiseen tyyliin. Se realistinen tai oikeastaan naturalistinen kuvaus, joka "meni muodista vossikan myötä", ei ole realismille millään tavoin olennainen; se saattoi ${ }^{3}$ jopa olla vain realismin korvike. Realistisen tradition näkemystä eivät toteuta inventaariokirjaukset kauppojen, takahuoneiden tai asemahallien sisällöstä. Sellaisia voidaan käyttää osana realistista tointa, mutta ne eivät ymmärtääkseni ole realismin käsitteen ydin. Jos niitä käytetään pitäen tarkkaa kuvailua itseisarvona, ne voivat itse asiassa kutakuinkin tuhota sen tasapainon, joka on tämän metodin olennaisin osa. Ne voivat esimerkiksi siirtää huomion ihmisistä esineisiin. 1920-luvulla realismin maineenmenetyksen taisikin aiheuttaa juuri tuntemus siitä, että täyteenkalustetussa romaanissa oli läsnä kaikki muu paitsi yksilöllinen elämä. Äärimmäinen tuolloinen reaktio siihen taas löytyy Virginia Woolfin Aalloista, jossa kaikki huonekalut ja jopa fyysiset ruumiit ovat lentäneet ulos ikkunasta niin, että jäämme äänien ja tuntojen seuraan, ilmassa roikkuviin ääniin - realismin kannalta aivan yhtä vahingollinen epätasapaino, kuten nyt voidaan nähdä.

Ääriviivoiltaan tradition tila voidaankin vetää yhteen näin: realistiseksi kutsumani romaani eli luomus, jossa elämäntavan aines ja laatu hahmottuu henkilöiden aineksen ja laadun puitteissa, hajoaa kahdeksi erilliseksi perimäksi: "sosiaaliromaaniksi" ja "persoonaromaaniksi". Sosiaaliromaanissa [the social novel] saattaa olla tarkkoja havaintoja ja kuvailuja yleisestä elämästä, sen kertymästä. Persoonaromaanissa [the personal novel] saattaa olla täsmällisiä huomautuksia ja kuvailuja henkilöistä, yksiköistä. 
Kummastakin puuttuu ulottuvuus, sillä elämäntapa kaikkineen ei ole kertymä eikä yksikkö, vaan kokonainen, jakamaton prosessi.

Annan tässä joitakin esimerkkejä tradition jakaantuneista puolista sekä niiden merkittävistä alalohkoista. On syytä huomauttaa, että kummankin linjan tapauksessa käsittelen vain niitä teoksia, jotka muistuttavat realistista romaania, vaikka muunkinlaisia löytyisi.

\section{[Dokumentoiva sosiaalinen kuvailu]}

Esittämääni tapaan ajatellen voidaan aluksi mainita kuvaileva, dokumentoiva sosiaalinen romaani. ${ }^{4}$ Sen prioriteettina on hahmottaa yleistä elämäntapaa kuvaamalla jotain tiettyä yhteiskunnallista tai työskentelevää ryhmää. Siihen voi tietysti sisältyä henkilöitä, jotka ovat joskus hyvinkin tarkasti piirrettyjä. Mutta tällaisista romaaneista tapaamme sanoa, että tässäpä oiva kirja sille, joka haluaa tietää elämästä kaivoskaupungissa tai kauppalaivassa, balettikoulussa tai Burman sotilaspartiossa.

On kyllä aivan totta, että monet näistä romaaneista ovat arvokkaita; hyvä dokumentointi on lähes aina kiinnostavaa. On peräti tärkeää kirjoittaa tällaisia romaaneja jatkossakin, mahdollisimman moniin asetelmiin sijoitettuna. Mutta ulottuvuus, joka jää puuttumaan, on ilmeinen: henkilöt ovat kaivosmiehiä, sotilaita, tanssijoita - vasta ensikuvauksia elämäntavasta. Tämä ei ole se painotus, jota olen yrittänyt hahmotella eli jossa omistaudutaan henkilöille samalla, kun heidät silti nähdään kiinteänä osana koko elämäntapaa. Tätä ulottuvuutta ei voida tavoittaa myöskään sattumanvaraisen arkisesti, vaikkapa istuttamalla ydinfyysikoista kertovaan romaaniin (vrt. Snow'n The New Men) pikkuisen rutiininomaista tavallista elämää, mikä yleensä tarkoittaa tavallista seksiä.

Kaikista nykyisistä romaanin tyypeistä tämä on, parhaimmillansa, näennäisesti lähinnä realistista traditiota. Mutta kuten olen yrittänyt selventää, keskeinen ero on luettaessa mitä ilmeisin: sosiaalisen kuvailun funktio on leimallisen ensisijainen.

\section{Tulevaisuustarina yhteiskuntakaavan mallintajana}

Huomattavan eläväinen ja suosittu on sosiaaliromaanin toinen muoto, joka on hyvin erilainen kuin edellinen. Sen otteena ei ole kuvailu, vaan se pyrkii löytämään yhteiskunnasta kaavan, formulan, ja materialisoimaan sen. Sosiaalisen kokemuksen summasta abstrahoidaan erityinen säännönmukaisuus ja sille perustuva yhteiskunta.

Yksinkertaisimmat osoitukset yhteiskuntakaavaa mallintavasta romaanista löytyvät tulevaisuustarinoiden [the future story] piiristä. Niissä "tulevaisuus" on ilmaisuväline (yleensä tosiaan vain ilmaisuväline, sillä lähes aina kirjoitetaan varsin selvästi nyky-yhteiskunnasta), jolla siirretään toisaalle tavanmukainen jännite valitun säännönmukaisuuden ja sen tarkastelun välillä. Romaanit kuten Uljas uusi maailma, Vuonna 1984 ja Fahrenheit 242 ovat voimakasta sosiaalista fiktiota, jossa nykyisestä yhteiskun- 
nasta uutettu säännönmukaisuus materialisoidaan toisessa ajassa tai paikassa. Muihin esimerkkeihin kuuluvat Goldingin Kärpästen herra ja Perilliset sekä liki kaikki vakava "science fiction". Useimmille näistä on luonteenomaista, että ne on kirjoitettu muistuttamaan realistisia romaaneja ja että ne operoivat samoin peruskeinoin.

On jälleen sanottava, että monet näistä romaaneista ovat arvokkaita, vaikkakaan en satu pitämään niiden yleisjuurena olevasta tarinamallista, jossa hyveellinen yksilö tai pienryhmä on asetettu vastakkain viheliäisen yhteiskunnan kanssa. On kovin helppoa tehdä yhteiskunta valikoinnin tai paisuttelun keinoin katalaksi, ja on aina ollut maailman helpointa esittää yksilö, minut, hyveelliseksi. Tulevaisuustarinoissa keskitytään laukomaan julki olemassa olevia henkilösuhteiden ja yhteiskunnan (erityisesti luokkaan liittyviä) jännitteitä - mutta sanon tarkoituksella "laukomaan julki” [release], sillä ne eivät varsinaisesti työstä noita jännitteitä. Tyypillisesti tehokeinona on lähinnä muuntaa jännitteitä hitusen, sijoittaa ne ennalta valittuun valoon, ei niinkään ymmärtää kuin ruokkia niitä. Kokemus eristyneisyydestä, vieraantumisesta tai henkisestä maanpakolaisuudesta on tietysti olennainen osa nykyistä tuntemusrakennetta, ${ }^{5}$ ja ollakseen realistinen minkä tahansa nykyromaanin pitäisi kohdata se kunnolla. (On ironista ja kertovaa, että niin Rikos ja rangaistus kuin - Bezuhovin kautta - Sota ja rauha kohtasivat sen ja ratkoivat sitä toisin kuin nykykaava "maanpakolaisuus vs. massat, pattitilanne".) Mainitut tulevaisuusromaanit ovat elinvoimaisia, koska ne kertovat elävistä sosiaalisista tuntemuksista, mutta niiden puute on se, että yhteiskuntakaava ei ole substantiaalinen yhteiskunta. Lisäksi henkilöt ovat yleensä ottaen mallinukkeja, joita määrittää ensisijaisesti rooli kaavassa.

\section{[Persoonakuvailua ja taustakankaita]}

Luonnostelmassani katson realistisen romaanin siis jakautuneen "sosiaaliseksi" romaaniksi ja "persoonalliseksi" romaaniksi. Sosiaaliromaani on nyt edelleen jakautunut dokumentoivaksi sosiaaliseksi kuvailuksi ja "yhteiskuntakaavaksi" [social formula]. Vastaava alajako voidaan nähdä persoonaromaanissa.

Yksi persoonaromaanin alatyyppi ovat valikoituja henkilösuhteita - herkästi ja huolellakin - kuvailevat romaanit. ${ }^{6}$ Usein ne muistuttavat kuvailemani realistisen romaanin osia, ja niihin kuuluu merkittäviä, tämän muodin puitteissa vilpittömiä teoksia. Käypä osoitus on Forsterin Matka Intiaan, jossa kyllä on vielä näkyviä jälkiä vanhasta tasapainosta mutta joka jo kuuluu esimerkillisesti tähän jakautuneeseen tyyppiin. Nimittäin romaanin kuvassa intialaisesta yhteiskunnasta on elementtejä, jotka romantisoivat aktuaalista yhteiskuntaa mukaillessaan tiettyjen henkilöhahmojen tarpeita. Näin tämäntyyppisessä "persoonallisessa" romaanissa juuri käy: yhteiskunnan taso yleisenä elämäntapana on näennäisesti mukana, mutta käytännössä mittavasti personalisoituna maisemana, selventämässä tai kehystämässä yksilömuotokuvaa - ei niinkään maana, 
jossa yksilöt rakentuvat. Graham Greenellä sosiaaliset kehykset ovat päivänselvästi juuri tällaisia: hänen Brightonillaan, Länsi-Afrikallaan, Meksikollaan ja Indokiinallaan on yhteisiä peruspiirteitä, jotka eivät kytkeydy alueiden aktuaalisiin elämäntapoihin vaan kirjailijan ja hänen henkilöidensä emotionaaliseen muottiin. ${ }^{7}$ Romaanilta puuttuva ulottuvuus on siis vastaava kuin sosiaalikuvailussa, mutta käänteinen. Siinä missä sosiaalikuvailun henkilöt olivat yhteiskunnan aspekteja, nyt yhteiskunta on henkilöiden aspekti. Peräänkuuluttamani painotus kuitenkin olisi saada sekä yleinen elämäntapa että yksilöpersoonat näkyville toisiaan kumoamattomina.

Persoonaromaaneissa käy tietysti niinkin, että vaikka ne olisivat lajissaan oivia, ei yleinen elämäntapa aina esiinny niissä edes tähän osittaiseen tapaan, vaan ainoastaan simppelinä taustakankaana, jossa näkyy shoppailua, sodan syttyminen, busseja sekä satunnaisia sivuhenkilöitä toisesta yhteiskuntaluokasta. ${ }^{8}$ Myönnän jälleen, että sellaisetkin romaanit voivat olla tärkeitä. Ne ovat usein sikäli mainioita, että ne ovat tulosta tarkoituksenmukaisesta valikoinnista ja keskittymisestä - sillä onhan olemassa laaja merkityksellisten kokemusten kenttä, jota voidaan tutkiskella kiehtovasti ihan vain siihen tapaan. Tietoinen valikointi ja keskittyminen on vaikkapa Proustilla aivan oikeutettua ja tuottaa epäsuorasti laajakuvan yleisestä elämäntavasta. Mutta näyttää siltä, että jokaista tietoista valikointia kohti on sata tapausta, joissa rajoittuminen on vain ja ainoastaan tietoisuuden epäonnistumista: ei pystytä oivaltamaan, missä määrin yleisen elämän ainekset vaikuttavat aktiivisesti intiimeimpäänkin kokemukseen.

Saattaa olla, että näille kirjailijoille yhteiskunnasta on tullut se tylsä abstrakti olio, jota sosiaaliromaani pahimmillaan tyrkyttää, eikä sikäli olisi yllättävää, jos he eivät näe, miksi heidän pitäisi antaa yhteiskunnan vaivata päätään. He vaativat saada ottaa ihmiset ennen muuta ihmisinä, ei yhteiskuntasoluina, ja tavallaan he ovat oikeassa reagoidessaan näin. Mutta sisällöstä jää uupumaan yleisten ainesten elementti, mikä hassusti paljastuukin otteen herkkyyden äkillisenä laskuna silloin, kun pitäisi kohdata joku toisesta yhteiskuntaluokasta ennen muuta ihmisenä. He eivät osaa ottaa yksilöpersoonana esimerkiksi siivoojaeukkoa - niin kuin he tätä tapaavat nimittää lainaten nyt äkisti sosiaaliromaanin kategorioita. ${ }^{9}$ Rivien välistä voi joskus kuulla, että me olemme ihmisiä, meille nämä asiat ovat tärkeitä. Sellaisen voisi diagnosoida yhteiskunnalliseksi snobbailuksi, mutta kyse on pikemminkin siitä, että he eivät onnistu tajuamaan yleisen yhteiskunnallisen elementin ilmenemistä omassa elämässään. Me olemme ihmisiä, tuosta noin vain; loput on maailmaa tai yhteiskuntaa tai politiikkaa tai mitä lie, tylsiä hommia joista kirjoitetaan sanomalehdissä. Vaan faktuaalisesti ottaenhan me olemme ihmisiä ja ihmisiä yhteiskunnassa - ja se kokonaisnäkemys oli realistisen romaanin keskiössä. 


\section{"Persoonakaavan" romaani}

Vuosisadan painavimpien romaanien joukkoon kuuluu kaikesta huolimatta myös iso joukko kyseisiä kerronnassaan persoonakeskeisiä romaaneja, ja kuten sanottu sellaistenkin puitteissa voidaan tehdä paljon, vaikka tämä ei olekaan, niin kuin olen väittänyt, sinänsä riittävästi. Vaan viimeisimmän sukupolven mittaan on sitten nähdäkseni heilahdettu myös poispäin tuontapaisesta persoonaromaanista kohti toisenlaista, nimittäin "persoonakaavan" romaania [the novel of the "personal formula"]. Kuten sosiaaliromaanin puolella, kokemusten summasta eristetään tietty säännönmukaisuus ja henkilöt luodaan sen pohjalta. Monesti näin syntyy puhuttelevaa, omine ehtoineen pätevää fiktiota - joskin vielä useammin tuloksena on jotain, mitä myöhempänä kutsun erityisyyteen vetoavaksi fiktioksi [the fiction of special pleading]. Kummassakin tapauksessa tällaisen romaanin perusolemus (laskematta mukaan ilmeisen ei-realistisia teoksia) on, että se ottaa vain yhden henkilön vakavasti - toki usein hyvin, hyvin vakavasti.

Tältäkin pohjalta on tietysti tehty hienoja töitä. Joycen teoksessa Taiteilijan omakuva nuoruuden vuosilta lähtökohta sisältyy jopa aivan keskeiseen otteeseen. Ja mainitessani tämän merkittävän teoksen tulenkin muistuttaneeksi siitä intensiteetin noususta, minkä tämä painotus mahdollistaa ja mikä on muodon varsinainen kehitysaskel. Maailma aktualisoidaan intiimisti yhden ihmisen aisteissa: ei kerrotun eikä käsivarrenmitan takana, vaan elettynä, sellaisenaan. Ulysseksessa Joyce näyttikin ne valtavat mahdollisuudet, jotka muodossa piilevät, kun hän teki maailman todeksi ei vain yhden, vaan kolmen henkilön kautta. On kolme näkemisen tapaa, kolme maailmaa, Stephenin, Bloomin ja Mollyn, ja kuitenkin kolme maailmaa ovat yksi eli romaanin koko maailma. Ulysses ei kylläkään säilytä tätä tasapainoa läpeensä; olennainen sommitelma sisältyy ensimmäiseen kolmannekseen, viimeinen osa jälkisoittona. Silti siinä toteutui realistinen traditio uudessa muodossa, tekniikaltaan muuttuneena mutta kokemisessaan herkeämättömänä.

\section{Amis ja Wain}

Ulysseksen jälkeen saavutus on laimennut tekniikan laimenemisen myötä. Caryn Jimson ja valaskala on kiinnostava esimerkki, sillä siihen on eristetty yksi näkemisen tapa, jonka mukaiseksi maailma on sovitettu. Sama analyyttinen huomio käy avaimeksi suosittuun uudenlaiseen romaaniin, jota edustavat Amisin Onnellinen Jim ja Virka ja viettelys sekä Wainin Living in the Present.

Kyseisten romaanien paradoksi on, että yhtäältä ne tuntuvat todellisimmalta nykykirjoittamiselta - vastaanotto oli lämmin, koska ne muistuttivat niin paljon aktuaalisia tuntemuksiamme - ja kuitenkin niiden viime versio todellisuudesta on parodinen ja farssinomainen. Tämä tosiasia kuvastaa mitä parhaiten yleistä ongelmaa: kirjoittajat 
lähtevät aidoista omakohtaisista tuntemuksista, mutta ylläpitääkseen ja havainnollistaakseen niitä sellaisena kuin ne on mukaan otettu, heidän on puristettava ympäröivää toiminnallista maailmaa karikatyyrimaiseksi. ${ }^{10}$ Jos he sijoittaisivat samat tunnot likeisemmin todelliseen maailmaamme eivätkä kriisissä farssitettuun versioon siitä, he joutuisivat tosiasiassa kyseenalaistamaan tuntemuksensa tai töin ja tuskin sovittelemaan niitä yhteen todellisuuden kanssa. Se, mitä nyt saadaan, ei ole asetelman tarkistusta vaan fantasiatason purkausta: kiroillaan puhelimessa, annetaan mukaluento tai löydetään Buchan-tyyppinen henkilö, ${ }^{11}$ jossa sosiaalinen aggressio tiivistyy. Nämä ovat eläväisimpiä kirjailijoitamme, ja siksipä he myös kuvastavat nykypulmaamme kaikkein ilmeisimmin. Tuntemustemme ja yhteiskunnallisen huomiokykymme välinen kuilu on vaarallisen leveä.

\section{Erityisyyteen vetoaminen}

Erityisyyteen vetoavaa fiktiota nähdään erityisesti niissä monissa nykyromaaneissa, jotka ottavat yhden henkilön tunteet ja tarpeet kiistattomina ja luovat toiset henkilöt tykkänään niiden ehdoin. Metodi alkaa jo Charlotte Brontësta, ja parhaillaan se kukkii peripopulaarissa minäkerronnassa, jota käytetään normaalisti tismalleen tällaisin tuloksin. ${ }^{12}$ Muuan variaatio on Saganin Tervetuloa ikävä, jossa henkilöt itse asiassa esitetään objektiivisesti, mutta laitetaan sitten toimimaan yhtäpitävästi keskushenkilön kuvitelmien kanssa. ${ }^{13}$ Bowenin The Heat of the Day seuraa vastaavaa peruskuviota, jossa henkilöt ovat ensisijaisesti päähenkilön emotionaalisen maiseman elementtejä; romaanissa tosin ei ole minäkertojaa, ja siinä on jopa varovaista kuvailevaa realismia - ikään kuin pehmentämässä vaatimusta yhdestä yksilöstä kuvatun maailman erityiskriteerinä.

Viime kädessä sama kuvio voi laajentua koskemaan sellaistakin romaania, joka näyttää vanhemmantyyppiseltä realistiselta romaanilta. Wilsonin romaanissa Epäjumala haudassa, jossa on ilmeinen realistinen tarkoitus, havainnoidaan lopulta vain yhtä henkilöä kokonaisena ja johdonmukaisesti; muut putoavat sivuun eriasteisiksi karikatyyreiksi, sen mukaan, mitä kauempana he hänestä ovat. ${ }^{14}$

\section{[Lopuksi]}

Esitän nelikohtaisen luokitteluni - sosiaalinen kuvailu ja yhteiskuntakaava, persoonakuvailu ja persoonakaava - tavaksi aloittaa yleistä analyysia nykyromaanista, sikäli kuin romaani tarjoutuu suorahkosti kuvaamaan jotakin osaa aikalaiselämästä. Niin ikään esitän sitä keinoksi määritellä, kontrastin kautta, realistista traditiota, jonka korvikkeiksi edelliset ovat eri tavoin asettuneet. Tässä suppeassa katsauksessa olen joutunut alistamaan teoksia ikään kuin sattumanvaraisiksi esimerkeiksi luokittelusta, vaikka tosiasiassa kävi niin, että yksityiskohtaiset analyysit tulivat ensin ja vasta myöhemmin havaitsin yleisen luokittelun nousevan esiin. 
Nyt kysymys kuuluu, vastaavatko kyseiset muodot johonkin muuntuneeseen todellisuuteen ja tekevätkö ne vanhemman tradition todella yhtä irrelevantiksi kuin vossikan. Vai ovatko ne kenties oireita jostakin hyvin syvästä kokemuksellisesta kriisistä, josta purskahtaa näitä eteviä anteja mutta joka tutkimatta jäädessään jatkaa muhimistaan ja jättää meidät viime kädessä tyytyväisyyttä vaille? Uskoakseni todisteet osoittavat jälkimmäiseen. En halua sanoa, että realistisen romaanin hylkääminen olisi jotenkin tarkoituksellista - että nämä kirjailijat kääntyisivät pois suuresta tradiosta tahallaan ja perverssiyttään, niin kuin monet tavalliset ${ }^{15}$ lukijat tuntuvat heistä ajattelevan. Kokemuksellinen kriisi on aivan liian syvä selittyäkseen moisella syyttelyllä. Mutta mikä sitten on tämä kriisi, sen yleinen luonne?

Tietyt taustat ovat välittömästi valaisevia. Realistinen romaani mitä ilmeisimmin tarvitsee alustakseen aitoa yhteisöllisyyttä: yhteisön, jossa ihmisten kiinnikkeet eivät ole vain yhden suhdetyypin - työn, ystävyyden, perheen - varassa, vaan monien toisiinsa kietoutuneiden. Yhteiskunnassamme on totta vie vaikea löytää tällaista yhteisöä. Siinä missä Middlemarch on intiimi-, perhe- ja työsuhteiden kompleksi ja saa voimansa niiden vuorovaikutuksesta jakamattomassa prosessissa, useimmissa nykyromaaneissa kytkökset henkilöiden välillä ovat verrattain yksittäisiä, väliaikaisia ja epäjatkuvia. Ja ennen kuin tämä muutos oli kirjallisen muodon muutos, se vaikutti jo yhteiskunnassa, ainakin siinä osassa yhteiskuntaa, joka likeisimmin koskettaa pääosaa nykykirjailijoista. Lisäksi siihen on liittynyt toisista syistä muovautunut, vuosisadalle luonteenomainen kokemus yksilöistymisestä ja yksilöllisyyden varjelusta - vastakkainen aiemmalle kokemukselle paikkansa löytämisestä ja aloilleen asettumisesta. Tyypillisessä viktoriaanisessa romaanissa loppuratkaisu on sarja asettumisia, uusia sitoumuksia ja muodollisten suhteiden solmimisia, niin kuin jokainen parodikko tietää; 1900-luvun keskivertoromaani taas päättyy siihen, että sankari lähtee kulkemaan omia polkujaan, kun hän ensin on taistellut vapauteen alistavasta tilanteesta ja löytänyt itsensä niin tehdessään. Sellaistakin ilmestyi yhteiskuntaan ennen kuin se taltioitiin kirjallisuuteen. Suurten muutosten aikoina tällainen poispääsyn ja löytämisen kokemus oli tarpeellinen ja arvokas liikahdus, ja yksilöllisten historioiden tallenteet tekivät yhteistä historiaa. Vaan tänä päivänä tuosta liikahduksesta, jota kirjallisuudessa yhä ylistetään, on tullut kuin rituaalista irrottautumista $^{16}$ - aikana, jolloin yhteiskunnallisessa keskustelussa silti ainakin muodollisesti kaivataan yhteisöllisyyttä, keskinäistä vastuuta ja yhteisiä ponnistuksia. Vanha valta toki kituuttaa aina ja sitä on syytä vastustaa jatkuvin riuhtaisuin. Mutta onhan se nyt sukupolvemme paradoksi, että kuulutamme yhteisöllisyyttä ja ylistämme pakenemista sen piiristä, huutelemme yhdistävien tuntemusten perään ja jaamme vain halun päästä pois. Kun sosiaalisen kuulumisen vakuuttelut ja yksilölliset osoitukset ovat näin erillään, on tietoisuudessa vaarallinen juopa, ja juuri siinä on realismin nykyinen kriisi.

Aukkoa voisi täyttää ideoin, uusin tulkinnoin ja löytämällä lojaliteetteja yhteiskunnan jatkuvan muuntumisen keskellä. Mutta sikäli kuin olen oikeassa, tätä kuilua 
ei pelkällä tahdolla silloiteta. Vaikka yhteiskuntamme puutteet rampauttavat meitä, emme ole valmiita luopumaan niistä murroksellisista poismurtautumisen arvoista, jotka nyt todella ovat elävää kokemustamme - emme kenenkään takia. Juopaa ylitettäessä tarvitaan niin laajaa selvittelyä, että siihen kuuluu välttämättä myös kaikkein vaikein integraatio: elvyttää se realistista romaania leimannut tuntemus persoonista ja koko elämäntavasta, jota olen kuvaillut. Tarvitsemme tämän kokonaisuudentunnon elpymistä aivan tavallisessa elämässä, mutta elpyminen edellyttää kokemuksellista oppimista ja virittäytymistä siihen tapaan kuin olen kuvannut vain realistisen romaanin voivan rekisteröidä. Siksi realistinen romaani on niin tärkeä. Jos elvytyksen resepti olisi yksinkertaisesti annettavissa, asemamme olisi toinen. Mutta resepti voidaan rustata, jos voidaan, vain sellaisin kokonaisehdoin, joiden yhdistämisen realistinen romaani mahdollistaa: niiden mukaan kaikki ihmiset ovat arvokkaita itsessään ja samalla heidän laatunsa ovat yhteisen elämäntavan laatuja. Siihen suuntaan olisi mentävä, ajattelen, ja vaikka vaiheet tulevat olemaan hitaita, tuo kokemuksellinen suunta voi jälleen muuntaa romaanin.

Sillä ei romaani kuollut ole. Sitä ei voida korvata yhtäältä sosiologialla ja toisaalta psykologialla eikä millään niiden kombinaatiolla pääkopassa. On hyviä aikalaisromaaneja, jotka kirjaavat tuntemuksia ja luonnehdintoja romaanin erityisellä välittömyydellä. Meidän on etsittävä niistä elvytystä asioiden likeiselle yhteenkietoutumiselle eli ajatusta tunteessa, persoonaa yhteisöllisyydessä ja muutosta asettumisessa - sitä, minkä George Eliot teki eläväksi Middlemarchissa tai Tolstoi Sodassa ja rauhassa. Tarvitsemme sitä kasvualustaksi jakautuneena aikanamme. Erityinen vastuu on mielestäni niillä, jotka ovat kasvaessaan tulleet tuntemaan tällaista likeistä yhteisöllisyyttä ja myöhemmin, niiden arvojen pohjalta, aikamme sosiaaliseen liikkuvuuteen kuuluvia muutoksia ja uudelleenarviointia. Siihen, miten he asian kokevat, voi itse asiassa sisältyä tulevaisuus eli yhteiskuntamme ajankohtaisesti mahdollinen suunta. Se, mitä he voivat tallentaa, jos he ovat uskollisia koko kokemukselleen, voi merkitä läpimurtoa yhteiskunnassa ja romaanissa.

\section{Viitteet:}

${ }^{1}$ Realism and the Contemporary Novel. Universities \& Left Review 4/1958, 22-25. Suom. Jussi Ojajärvi. (Korjausehdotuksista käännösvalintoihin kiitos Ralf Kauraselle.)

${ }^{2}$ Suomentajan huomautuksia: Alkuperäisessä julkaisussa väliotsikointi on mitä ilmeisimmin kyhätty kiireellä lehden toimituksessa, sillä otsikot eivät aina ole osuvia eivätkä artikkelia ymmärrettävästi jäsentävissä paikoissa; pikemminkin alkuperäinen väliotsikointi aiheuttaa vaikeuksia hahmottaa esseestä Williamsin esittämää realistisen tradition jakautuneisuutta (kaksi erillistä perimää, kummassakin kaksi alakohtaa ja niillä taas mahdollisia alakohtia). Artikkelin hieman myöhempi, pidempi versio eli The Long Revolutionin (1961) luku 7 ei sisällä lainkaan väliotsikoita eikä alalukujakoa. Tässä suomennoksessa on otettu toimituksellista vapautta parantaa väliotsikointia ja lukujakoa - lähinnä alkupuoliskolla - pitäen ohjenuorana tekstin informatiivisempaa jäsentymistä; samoista syistä on lisätty puolentusinaa kappalejakoa. 
Lisätyt väliotsikot ovat hakasulkeissa ja alkuperäisellä paikallaan olevat (joista kaikki ovat mukana) ilman sulkeita. Esseen alun ja lopun eroista vuoden 1961 versioon (josta käytössäni on vuoden 1965 Pelican-painos) puhutaan erikseen suomentajan kommentaareissa; useimmista pienemmistä eroista taas mainitaan näissä alaviitteissä.

${ }^{3}$ Vuoden 1961 versiossa Williams tarkentaa: "sellaisilla kirjailijoilla kuin [Arnold] Bennett".

${ }^{4}$ Williams käyttää tässä ilmaisua "the descriptive social novel, the documentary". Olen kääntänyt sanan "documentary" dokumentoinniksi, koska Williams ei tarkoita viitata mihinkään fiktiivisen ulottuvuuden kieltäviin dokumentaareihin, vaan käyttää sanaa väljemmästi puhuessaan fiktiivisestä romaanista.

${ }^{5}$ Williamsin structure offeeling on suomennettu tässä "tuntemusrakenteeksi”, mistä ks. saatekommentaarini.

${ }^{6}$ Williams antaa suorimman nimityksen tälle persoonakeskeisen romaanin toiselle merkittävälle alatyypille vasta esseen loppuosion alussa: "personal description", persoonakuvailu.

${ }^{7}$ Vuoden 1961 versiossa Williams $(1965,308)$ lisää: "Kun tämä on tehty suoraan ja ehdottomasti, kuten Kafkalla, ei ole ainakaan mitään epäselvyyttä; mutta tavallisesti esiintyy, realismin pinnan kera, tuttu epätasapaino."

${ }^{8}$ Vuoden 1961 lisäys (Williams 1965, 309): "Yhteiskunta on ihmisten ulkopuolella, vaikkakin se joskus, jopa väkivaltaisesti, murtuu heidän päälleen."

${ }^{9}$ Vuoden 1961 versiossa (Williams 1965, 309) siivoojaeukon kohdalla on suorempi viittaus, jota lainattakoon alkukielellä: "[T]he strange case of the Virginia Woolf'charwoman' or 'village woman', with the sudden icy drop in the normally warm sensibility, symbolizes a common limitation." Alustukseksi Williams on muotoillut: "Pienessä ryhmässä persoonallisuutta vaalitaan, mutta ryhmän ulkopuolella ei ole mitään."

${ }^{10}$ Vuoden 1961 versiossa Williams $(1965,311)$ lisää sulkeissa: "Tämä oli myös Dickensin menettely hänen ollessaan niillä rajoilla, mitä hän saattoi avoimesti nähdä tai todeta, ja karikatyyri ja sentimentaalisuus ovat tässä mielessä saman kolikon puolia, joita käytetään vältellessä pulman todellista välittämistä."

${ }^{11}$ Vuoden 1961 versiossa (olettaakseni John) Buchaniin viittaamisen sijaan: "löydetään tyyppifiguuri" (Williams 1965, 311).

${ }^{12}$ Erityisyyteen vetoavaa fiktiota käsittelevässä osuudessa on verrattain paljon uutta ainesta vuonna 1961. Williams mainitsee suhteuttavia lisäesimerkkejä: Huckleberry Finnissä on tämä tendenssi, mutta keskiosan maisema yleisempään todellisuuteen antaa persoonapainotukselle realistista henkeä; Sieppari ruispellossa sisältää pelastuksenaan ironiaa, mutta romaanin rajoitteet tulevat loppua kohti yhä selvemmin esille; John Brainen Elämää huipulla romahtaa täysin, koska siinä ei ole mitään ulkopuolista todellisuutta, johon viitata. Esimerkkinä kokonaisemmasta eli realistisesta ulottuvuuksien koonnasta taas on Carson McCullersin Member of the Wedding, jossa "fantasiaksi kasvava henkilökohtaisen tunteen todellisuus on väistämättä jännitteisessä vuorovaikutuksessa sen todellisuuden kanssa, jossa tunteita täytyy elää". (Williams 1965, 311.)

${ }^{13}$ Williams 1965, 311-312: "Sagan vertautuu McCullersin realismiin realismin romahduksena. Ja tämä on valitettavasti romahdus, josta meillä on eniten esimerkkejä: ensimmäisen persoonan kertomus, johon on uhrattu niin paljon teknistä taituruutta, on nyt tyypillinen mekanismi rationalisoida tuota romahdusta. Kuitenkin erityisyyteen vetoava fiktio pyrkii vielä muodollisesti muistuttamaan realistista fiktiota." 
${ }^{14}$ Vuoden 1961 versiossa on Wilsonia koskevan, omaksi kappaleekseen erottamani pätkän sijaan yhteenveto: "Persoonaromaani kehittyy nyt suuntaan, jossa se päätyy kieltämään henkilöistä useimmat. Yhteiskunnan todellisuus on suljettu ulos, ja tämä johtaa väistämättä lopulta siihen, että kaikki paitsi muutama yksilöllinen ihminen suljetaan ulos. Näissä oloissa ei sitten olekaan yllättävää, että kuvaillusta henkilökohtaisesta tuntemuksesta niin paljon täytyy olla henkilökohtaisen romahduksen kokemusta." (Williams 1965, 312.)

${ }^{15}$ Williams 1965, 312: "monet hämmentyneet".

${ }^{16}$ Tästä eteenpäin myöhempien versioiden loppu on erilainen (ks. Williams 1965, 313-316). 